\title{
UPAYA MENINGKATKAN MOTIVASI BELAJAR SISWA MELALUI METODE PEMBELAJARAN DISCOVERY PADA PEMBELAJARAN SEJARAH KELAS X DI SMA NEGERI 2 KOTA KOMBA
}

\author{
Floriana Liaristi Pandong ${ }^{1}$ \\ Arif Wahyu Hidayat ${ }^{2}$ \\ IKIP Budi Utomo Malang \\ liaristipandong@gmail.com ${ }^{1}$
}

\begin{abstract}
ABSTRAK
Permasalahan yang sering muncul dalam pembelajaran sejarah selama ini adalah rendahnya motivasi belajar siswa, sebab sebagian besar siswa menganggap sejarah sebagai mata pelajaran yang membosankan. Guru harus terus berusaha mengubah pola pikir siswa agar semakin menyukai dan termotivasi mempelajari mata pelajaran sejarah, salah satu caranya ialah dengan menerapkan metode pembelajaran discovery.

Penelitian ini menggunakan rancangan Penelitian Tindakan Kelas (PTK) yang dilakukan dalam dua siklus. Subjek penelitian ini adalah siswa kelas X SMA Negeri 2 Kota Komba pada semester 2 Tahun Ajaran 2017/2018, berjumlah 30 siswa. Instrumen penelitian ini adalah angket yang digunakan untuk mengukur motivasi belajar siswa.

Hasil penelitian ini menunjukkan bahwa persentase siswa kelas X SMA Negeri 2 Kota Komba yang termotivasi untuk mengikuti pembelajaran sejarah melalui metode discovery pada siklus 1 hanya $60 \%$. Berdasarkan hal tersebut, maka dapat disimpulkan penerapan metode pembelajaran discovery dapat meningkatkan motivasi belajar kelas X SMA Negeri 2 Kota Komba pada pembelajaran sejarah.
\end{abstract}

Kata Kunci: Motivasi Belajar, Discovery, Sejarah

\section{PENDAHULUAN}

Pendidikan nasional akhirakhir ini sering dibicarakan, baik melalui media masa maupun tulisan-tulisan ilmiah, yang mengungkap masih rendahnya kualitas pendidikan di Indonesia. Salah satu faktor penyebabnya adalah rendahnya rata-rata prestasi belajar siswa (Hamdani, 2017:43). Masalah lain dalam ranah pendidikan di Indonesia yang juga banyak diperbincangkan adalah bahwa 
pendekatan dalam pembelajaran masih terlalu didominasi peran guru (teacher centered). Pendidikan kita kurang memberikan kesempatan pada siswa dalam berbagai mata pelajaran untuk mengembangkan kemampuan berpikir holistik (secara menyeluruh), kreatif, objektif, dan logis, serta kurang memperhatikan aspek ketuntasan belajar secara individual. Belajar merupakan suatu usaha yang dilakukan individu untuk memperoleh suatu perubahan pengetahuan dan perilaku yang baru secara keseluruhan sebagai hasil pengalamannya dalam interaksinya dengan lingkungan.

Hal tersebut sejalan dengan pendapat Yamin (2015:11) yang menyatakan bahwa belajar merupakan "sebuah proses dimana tingkah laku dari suatu organisme dimodifikasi oleh pengalaman. Pengalaman dalam konteks belajar akan sangat memengaruhi sikap dan kebiasaan hidup seseorang ke depannya".

Apabila faktor-faktor yang menunjang keberhasilan proses belajar mengajar di sekolah itu terpenuhi, maka akan semakin memperlancar proses belajar mengajar, yang pada akhirnya akan dapat meningkatkan motivasi dan prestasi belajar siswa (Hamalik, 2013:17).
Motivasi merupakan faktor yang sangat penting dalam belajar, yang dapat menunjang pencapaian prestasi belajar. Motivasi belajar berkaitan erat dengan tujuan yang hendak dicapai oleh individu yang sedang belajar. Apabila seseorang yang sedang belajar menyadari bahwa tujuan yang hendak dicapai berguna atau bermanfaat baginya, maka aktivitas belajar akan muncul dengan kuat (Istiqomah, 2014:2). Memunculkan motivasi belajar siswa antara lain dapat dilakukan guru dengan cara memberikan pujian atau hadiah, menciptakan situasi atau kondisi belajar yang menyenangkan, memberi nasehat, kadang-kadang memberikan teguran. Kegiatan seperti itu sangat penting untuk dipertimbangkan di dalam membimbing siswa belajar. Motivasi siswa yang tinggi akan meningkatkan keaktifan belajar siswa, akan memicu usaha siswa untuk memahami materi-materi pelajaran, sehingga meningkatkan prestasi belajarnya (Haryanto, 2010:1).

Skenario pembelajaran yang dirancang secara tepat dapat mengatasi permasalahan rendah nya motivasi belajar siswa. Salah satu metode pembelajaran yang dapat diterapkan guru adalah discovery (penemuan). Metode discovery adalah metode pembelajaran yang menekankan pada upaya siswa agar 
dapat menggali potensi diri dalam merumuskan, memecahkan, meng analisis, serta menyimpulkan permasalahan berdasarkan data yang diperoleh melalui pembelajar an di bawah bimbingan dan pengawasan guru (Daniah, 2014:1). Metode discovery menekankan pada proses siswa menemukan sebuah konsep sehingga memunculkan sikap ilmiah pada diri siswa masingmasing. Metode pembelajaran discovery dapat dirancang penggunaannya oleh guru menurut kemampuan atau tingkat perkembangan intelektual siswa, karena siswa memiliki sifat yang aktif, sifat ingin tahu yang besar, terlibat dalam suatu situasi secara utuh dan reflektif terhadap suatu proses dan hasil-hasilnya yang ditemukan (Dewi, dkk., 2013:3-4). Discovery merupakan metode pembelajaran yang memberi kesempatan kepada siswa untuk mempelajari cara menemukan fakta, konsep dan prinsip melalui pengalamannya secara langsung. Metode pembelajaran discovery dilakukan secara berkelompok, di mana siswa diberi kesempatan untuk berfikir mandiri dan saling membantu teman sekelompoknya. Penerapan metode pembelajaran discovery juga dapat memicu tumbuhnya sikap atau motivasi siswa untuk terus belajar, karena kegiatan pembelajaran tidak lagi didominasi oleh guru, melainkan peran belajar bersama-sama dengan teman sebayanya. Penera pan model discovery learning berpengaruh signifikan terhadap motivasi belajar siswa". Hal tersebut didukung pula oleh hasil penelitian Anisa, dkk. (2017:283) yang menyimpulkan bahwa penerapan pembelajaran discovery dapat meningkatkan motivasi belajar dan penguasaan konsep siswa.

Berdasarkan uraian di atas, maka diprediksi bahwa penerapan metode pembelajaran discovery dapat meningkatkan motivasi belajar siswa. Oleh karena itu, maka dilakukan penelitian yang berjudul: Upaya Meningkatkan Motivasi Belajar Siswa Melalui Metode Pembelajaran Discovery pada Pembelajaran Sejarah Kelas X di SMA Negeri 2 Kota Komba.

Tujuan Penelitian ini adalah untuk mengetahui peningkatan motivasi belajar siswa melalui metode pembelajaran discovery pada pembelajaran sejarah kelas X di SMA Negeri 2 Kota Komba.

Kegiatan penelitian ini ditujukan untuk menganalisis upaya meningkatkan motivasi belajar siswa melalui metode pembelajar an discovery pada pembelajaran sejarah kelas $X$ di SMA Negeri 2 Kota Komba. Namun, ruang 
lingkup tersebut peneliti anggap masih cukup luas, karena peneliti memiliki keterbatasan untuk melaksanakannya, baik karena faktor waktu, pembiayaan, dan tenaga. Oleh karena itu, maka perlu dibatasi ruang lingkup itu dengan tujuan agar tidak memunculkan harapan yang berlebihan dalam penelitian ini.

\section{METODE PENELITIAN}

\section{Rancangan penelitian ini merupakan Penelitian Tindakan Kelas} (PTK). Hal ini dikarenakan peneliti berupaya meningkatkan motivasi belajar siswa melalui metode pembelajaran discovery pada pembelajaran sejarah kelas $X$ di SMA Negeri 2 Kota Komba. Menurut Rahim (2009:22), Penelitian Tindakan Kelas (PTK) termasuk jenis penelitian kualitatif , sehingga analisis datanya bersifat siklus. PTK adalah "penelitian tindakan yang dilakukan di kelas dengan tujuan untuk memperbaiki atau meningkatkan mutu praktik pembelajaran" (Arifin, 2010:190). Analisis data pada setiap siklus Penelitian Tindakan Kelas (PTK) meliputi, sebagai berikut:

1. Perencanaan (planning), disus un dengan tujuan untuk mempe rbaiki proses dan hasil pembelajaran yang berisi tujuan yang harus dicapai, serta lebih ditonjolkan perlakuan guru dalam kegiatan pembelajaran (Arifin, 2010:223). Perencanaan pembelajaran disusun dengan mengacu pada hasil evaluasi pembelajaran sebelumnya deng an tujuan untuk memperbaikinya.

2. Pelaksanaan tindakan (action), merupakan segala bentuk perlakuan yang dilaksanakan guru berdasarkan perencanaan yang telah disusun dan mengacu pada fokus masalah. Tindakan dilaksanakan dalam program pembelajaran apa adanya (Arifin, 2010:224-225). Dengan demikian, maka tindakan itu tidak direkayasa untuk kepentingan penelitian, namun dilaksanakan sesuai dengan program pembelajaran yang disusun.

3. Pengamatan (observation), dilak ukan dengan tujuan mengumpul kan informasi tentang pembela jaran. Halhal yang diobservasi meliputi kelemahan dan kekuatan pembelajaran, sehing ga dapat dijadikan masukan saat refleksi untuk menyusun rencana ulang siklus berikutnya (Arifin, 2010:225-226).

4. Refleksi (reflection), adalah aktivitas melihat berbagai kekurangan dari hasil observasi pembelajaran, sehingga guru dapat mencatat berbagai kekurangan yang perlu diperbaiki, yang 
menjadi dasar dalam penyusunan rencana ulang (Arifin, 2010:226-227).

Penelitian ini dilaksanakan di kelas X SMA Negeri 2 Kota Komba. Alasan pemilihan lokasi penelitian tersebut adalah karena berdasar kan hasil observasi awal menunjukkan bahwa motivasi siswa untuk aktif dalam pembelajaran sejarah sangat kurang. Hal ini dibuktikan dari sedikitnya siswa yang mau bertanya atau menjawab pertanya an guru saat proses pembelajaran berlangsung, bahkan saat guru memberi tugas banyak siswa yang tidak mengerjakan. Salah satu penyebab rendahnya motivasi belajar siswa adalah pembelajaran selama ini didominasi oleh guru, sedangkan peran aktif siswa sangat kurang.

Guru cenderung mengajar menggunakan metode ceramah dan penugasan sehingga peran guru dominan daripada siswa. Minimnya aktivitas siswa dalam kegiatan pembelajaran itulah yang kemudian menyebabkan rendah nya motivasi siswa untuk belajar. Penelitian ini dilaksanakan dalam kurung waktu tujuh (7) minggu, mulai dari tahap perencanaan awal siklus 1 hingga berakhirnya pembelajaran siklus 2. Pelaksanaa nnya adalah mulai dari tanggal 19 Februari 2018 hingga 5 April 2018. Subjek yang terdapat dalam penelitian ini adalah siswa kelas $X$
SMA Negeri 2 Kota Komba pada semester 2 Tahun Ajaran 2017/2018, yang berjumlah 30 siswa.

Penelitian Tindakan Kelas (PTK) ini dilaksanakan dalam dua siklus dan pelaksanaannya mengacu pada langkahlangkah PTK yang telah peneliti uraikan di atas. Masing-masing siklus mencakup empat tahapan, yaitu perencanaan, tindakan, observasi, dan refleksi. Tindakan pada siklus 2 dilaksanakan apabila hasil pembelajaran pada siklus 1 menunjukkan bahwa target penelitian ini belum tercapai.

\section{Siklus 1}

Tindakan siklus 1 dilakukan dengan tujuan untuk meningkat kan motivasi belajar siswa pada pembelajaran sejarah melalui penerapan metode discovery. Apabila hasil refleksi siklus 1 nantinya menunjukkan minimal $80 \%$ siswa yang skor angket motivasi belajarnya $\geq 123$ maka penelitian dihentikan, namun jika < $80 \%$ siswa yang skor angket motivasi belajarnya $\geq 123$ maka tindakan akan dilanjutkan menuju siklus 2. Pelaksanakan penelitian tindakan kelas pada siklus 1 ini meliputi tahap-tahap, sebagai berikut:
A. Perencanaan Tindakan Siklus 1 Merencanakan kegiatan pembe lajaran sejarah dengan menggu nakan metode discovery.Menen 
tukan materi, yaitu tradisi sejarah masyarakat Indonesia. Merancang kegiatan pembelaja ran sejarah pada materi tradisi sejarah masyarakat Indonesia dengan metode discovery.

B. Pelaksanaan Tindakan Siklus 1

Peneliti menerapkan pembelaja ran sejarah pada materi tradisi sejarah masyarakat Indonesia melalui metode discovery. Peneliti secara mandiri bertindak sebagai guru yang bertanggung jawab penuh terhadap kegiatan pembelajar an. Kegiatan pembelajaran pada siklus 1 dilaksanakan dalam 2 (dua) kali pertemuan.

C. Pengamatan Siklus 1 Tahap ini, peneliti memberikan angket motivasi belajar kepada seluruh siswa di akhir pengamatan siklus 1 . Tujuan siswa diberikan angket adalah untuk mengevaluasi motivasi siswa selama mengikuti kegiatan pembelajaran siklus 1 tersebut.

D. Refleksi Siklus 1 Tahap refleksi pembelajaran siklus 1, guru menganalisis hasil tindakan siklus 1 , berkaitan dengan aspek atau permasalahan-permasalahan yang telah dan belum berhasil dipecahkan setelah pembelajar an siklus 1 . Berdasarkan hasil analisis tindakan siklus 1, apabila hasilnya menunjukkan bahwa target keberhasilan penelitian belum tercapai maka disusun perencanaan tindakan lanjutan menuju siklus 2 dengan menganalisis berbagai permasalahan yang belum berhasil dipecahkan dalam pembelajaran siklus 1.

\section{Siklus 2}

Tindakan pada siklus 2 dilaksanakan jika < $80 \%$ siswa yang skor angket motivasi belajarnya $\geq 123$. Pelaksanakan tindakan pada siklus 2 ini meliputi tahap-tahap, sebagai berikut:

A. Perencanaan Tindakan Siklus 2 Memperbaiki rancangan pem belajaran sejarah materi tradisi sejarah masyarakat Indonesia melalui discovery. Perbaikan mengacu pada permasalahan yang ditemukan selama proses pembelajaran siklus sebelum nya dan solusi yang telah dirumuskan.

B. Pelaksanaan Tindakan Siklus 2 Pelaksanaan tindakan siklus 2 mengacu pada masalah yang muncul pada siklussebelumnya dan solusi yang dirumuskan. Peneliti kembali menjadi guru 
yang menerapkan lag pembelajaran sejarah pada materi tradisi sejarah masyarakat Indonesia melalui metode discovery.

C. Pengamatan Siklus 2 Tahap ini, peneliti kembali memberikan angket motivasi belajar kepada seluruh siswa di akhir pengamatan siklus 2. Tujuan siswa diberikan angket adalah untuk mengevaluasi motivasi siswa selama mengikuti kegiatan pembelajar an siklus 2 tersebut.

D. Refleksi Siklus 2 Tahap ini, guru menganalisis hasil tindakan siklus 2 , berkaitan dengan permasalah an yang telah dan belum berhasil dipecahkan. Setelah diberi tindakan siklus 2, diharapkan motivasi belajar siswa pada pembelajaran sejarah semakin meningkat, yang ditunjukkan dengan minimal $80 \%$ siswa secara klasikal memperoleh skor angket motivasi belajar $\geq 123$.

Instrumen yang diperlukan dalam penelitian ini yaitu angket (questionnaire). Angket dalam penelitian ini digunakan untuk memperoleh informasi/ data tentang motivasi belajar siswa. Angket diberikan kepada siswa sebanyak dua kali, yaitu di akhir siklus 1 dan siklus 2. Tujuannya adalah untuk mengetahui perubah an atau peningkatan motivasi belajar dari para siswa setelah siswa diajar mata pelajaran sejarah materi tradisi sejarah masyarakat Indonesia melalui metode discovery. Pernyataan yang disajikan dalam angket mempunyai sifat positif (+) dan negatif (-), serta menggunakan skor untuk setiap jawaban yang dipilih responden. Skor jawaban yang diperoleh merupakan skala ordinal dengan tujuan agar dapat dianalisis dan diangkakan menggunakan skala Likert lima tingkatan, yaitu 1 sampai 5 . Rincian pemberian skor tiap jawaban ialah:

Tabel Pemberian Skor pada Jawaban Angket

\begin{tabular}{|c|c|c|}
\hline \multirow{2}{*}{ Alternatif Jawaban } & \multicolumn{2}{|c|}{$\begin{array}{l}\text { Skor untuk } \\
\text { Pertanyaan }\end{array}$} \\
\hline & $\begin{array}{l}\text { Positif } \\
(+)\end{array}$ & $\begin{array}{l}\text { Negatif } \\
(-)\end{array}$ \\
\hline Sangat Setuju (SS) & 5 & 1 \\
\hline Setuju (S) & 4 & 2 \\
\hline Ragu-ragu (R) & 3 & 3 \\
\hline Tidak & 2 & 4 \\
\hline Setuju (TS) & & \\
\hline
\end{tabular}




\begin{tabular}{|l|l|l|} 
Sangat & 1 & 5 \\
Tidak & & \\
Setuju (STS) & & \\
\hline
\end{tabular}

Angket di atas harus mempunyai kelayakan dalam rangka menjaring, mengungkap, menyadap, mengukur semua informasi berupa data yang akan diolah, sehingga perlu dilakukan uji validitas (kesahihan) dan reliabilitas (konsistensi) terlebih dahulu. Analisis data penelitian ini dilakukan dengan tujuan mengu kur motivasi belajar siswa pada pembelajaran sejarah materi tradisi sejarah masyarakat Indonesia setelah diajar melalui discovery,sehingga dapat diperoleh informasi tentang perubahan atau peningkatannya.

Teknik analisis data yang digunakan yaitu deskriptif persentase, dengan rumus:

$\mathrm{fN}$

$P=x 100 \%$

$=\mathrm{N}$

Keterangan:

$P=$ Persentase

$\mathrm{fN}=$ Jumlah siswa yang termotivasi

$\sum N=$ Jumlah seluruh siswa

Data-data yang dianalisis meliputi rata-rata jumlah siswa yang termotivasi dan persentase motivasi siswa dalam pembelajar an sejarah, dengan kategori sebagaimana peneliti uraikan dalam tabel berikut ini.

Tabel Kategori Tingkat Motivasi Belajar Siswa

\begin{tabular}{|l|l|}
\hline Kategori Motivasi & $\sum$ Skor Angket \\
\hline Sangat Tinggi (ST) & $152-180$ \\
Tinggi (T) & $123-151$ \\
Cukup Tinggi (CT) & $94-122$ \\
Rendah (R) & $65-93$ \\
Sangat Rendah & $36-64$ \\
(SR) &
\end{tabular}

Indikator keberhasilan peneli tian ini adalah meningkatnya motivasi belajar siswa pada mata pelajaran sejarah, yang ditunjukk an dengan minimal $80 \%$ siswa secara klasikal memperoleh total skor angket $\geq 123$.

\section{PEMBAHASAN}

Penelitian Tindakan Kelas (PTK) ini dilaksanakan di Sekolah Menengah Atas (SMA) Negeri 2 Kota Komba. SMA Negeri 2 Kota Komba merupakan salah satu SMA negeri yang ada di Kabupaten Manggarai Timur, yang tepatnya beralamat di Desa Mbengan Kecamatan Kota Komba Kabupaten Manggarai Timur Provinsi 
Nusa Tenggara Timur (NTT). Prasarana yang ada di SMA Negeri 2 Kota Komba memang tergolong sudah cukup memadai atau lengkap, namun demikian kondisinya saat ini sudah banyak yang rusak. SMA Negeri 2 Kota Komba telah memiliki sebuah kantor Tata Usaha (TU), 1 ruang guru dan 1 ruang kepala sekolah, 9 ruang kelas, 1 perpustakaan, 2 laboratorium, serta 2 sanitasi siswa. Selain itu, SMA Negeri 2 Kota Komba juga telah memiliki sebuah lapangan sepak bola, yang difungsikan untuk kegiatan pembelajaran olahraga. Jumlah guru di SMA Negeri 2 Kota Komba pada Tahun Ajaran 2017/2018 sebanyak 20 orang, serta jumlah pegawai sebanyak 2 orang. Jumlah siswa di SMA Negeri 2 Kota Komba untuk Tahun Ajaran 2017/2018 total sebanyak 176 siswa (81 siswa laki-laki dan 95 siswa perempuan), yang terbagi ke dalam tiga tingkatan kelas, mulai dari kelas $\mathrm{X}$ hingga kelas XII. Kelas $\mathrm{X}$ hanya terdiri dari satu rombongan belajar yang totalnya berjumlah 30 siswa, kelas XI terdiri dari tiga rombongan belajar yang totalnya berjumlah 89 siswa, serta kelas XII terdiri dari dua rombongan belajar yang totalnya berjumlah 57 siswa.

Hasil penelitian ini memapar kan tentang kegiatan-kegiatan yang peneliti dilakukan selama melaksanakan penelitian sesuai dengan tahap-tahap PTK, baik pada siklus 1 maupun siklus 2 . Pengamatan dilakukan untuk melihat tinggi-rendahnya motivasi belajar sejarah siswa melalui metode discovery. Evaluasi dilakukan melalui angket, di mana semua siswa menjawab angket motivasi belajar secara mandiri, lalu guru menilai jawaban angket mereka. Tahap analisis data dilakukan sesudah seluruh kelompok menempuh proses pengumpulan data. Proses analisis data dilakukan dengan cara masing masing kelompok mempre sentasikan hasil pengolahan datanya di depan kelas, di mana masing-masing anggota kelompok harus dapat menyampaikan minimal satu ide hasil pengolahan data kelompoknya. Pada tahap ini, siswa yang tidak mampu memberikan kontribusi untuk kelompoknya dikenakan sanksi yaitu membayar denda berupa uang sesuai dengan kesepakatan bersama.

Tahap penarikan kesimpulan, guru menunjuk siswa-siswa untuk menyimpulkan jawaban secara lisan dari pertanyaan-pertanyaan yang telah dianalisis kelompoknya. Siswa yang mampu mengemukak an kesimpulan dengan benar diberi penghargaan (uang atau alat tulis) oleh guru. Pengamatan terhadap motivasi belajar sejarah siswa 
kembali dilakukan pada siklus 2. Evaluasi

motivasi belajar siswa dilakukan dengan mengguna kan angket yang berisi pernyataanpernyataan tentang motivasinya mengikuti kegiatan pembelajaran sejarah pada siklus 2 . Semua siswa diberi angket, lalu diminta untuk menjawab semua pernyataan dalam angket tersebut, lalu jawaban siswa diberi skor oleh guru.

Berdasarkan hasil penelitian berupa pembelajaran sejarah melalui metode discovery pada siswa kelas X SMA Negeri 2 Kota Komba seperti diuraikan di atas, maka peneliti merefleksi bahwa kegiatan pembelajaran tersebut telah dapat dilakukan dengan baik dan terbukti mampu meningkatk an motivasi belajar sejarah siswa. Hal tersebut dapat dilihat dari skorskor angket motivasi belajar yang dicapai siswa, yang semakin meningkat mulai dari siklus 1 hingga siklus 2 .

\section{KESIMPULAN}

Berdasarkan hasil penelitian dan pembahasan seperti yang diuraikan pada bab sebelumnya, diketahui persentase siswa kelas X SMA Negeri 2 Kota Komba yang termotivasi untuk mengikuti pembelajaran sejarah melalui metode discovery pada siklus 1 hanya $60 \%$. Namun, persentase tersebut semakin meningkat menjadi $90 \%$ setelah diterapkan pembelajaran pada siklus 2 . Hal ini menjelaskan bahwa persentase siswa kelas X SMA Negeri 2 Kota Komba yang termotivasi untuk mengikuti pembelajaran sejarah melalui metode discovery semakin meningkat dari siklus 1 ke siklus 2. Berdasarkan uraian di atas, maka dapat disimpulkan penerapan metode pembelajaran discovery dapat meningkatkan motivasi belajar kelas $X$ SMA Negeri 2 Kota Komba pada pembelajaran sejarah.

\section{DAFTAR RUJUKAN}

Daniah. 2014. Penggunaan Metode Penemuan Terbimbing pada Mata Kuliah IPA Terhadap Sikap IImiah dan Hasil Belajar Mahasiswa Jurusan PGMI UIN Ar-Raniry. Jurnal PGMI UIN Ar-Raniry, Vol. 1 No. 1, hal. 114 .

Dewi, N. L., N. Dantes \& I W. Sadia. 2013. Pengaruh Metode Pene muan Terbimbing Terhadap Sikap Imiah dan Hasil Belajar IPA. E Journal Pendidik an Dasar Undiksha, Vol. 3 No. 3, hal. 1-10.

Hamalik, O. 2013. Proses Belajar Mengajar. Cetakan $15 . \quad$ Jakart a: Bumi Aksara.

Hamdani. 2017. Hubungan Kompet ensi Pedagogik dan Motivasi Mengajar dengan Hasil Belajar Siswa Kelas XI pada Mata Pelajaran Fikih di MAN 2 
Metode Medan. Jurnal Ansiru, Vol.

1 No. 1, hal. 4363.

.Istiqomah, F. 2014. Penerapanan Model Guided Discovery Lear ning untuk Meningkatkan Motivasi dan Hasil Belajar Siswa. Jurnal IImiah FKIP Universitas Lampung, Vol. 1 No. 1, hal. 1-9.

Yamin, M. 2015. Teori dan Metode Pembelajaran: Konsepsi, Strat egi dan Praktik Belajar yang Membangun Karakter. Malang: Madani 